\title{
Epistemologi Keilmuan Integratif-Interkonektif M. Amin Abdullah dan Resolusi Konflik
}

\author{
Dendi Sutarto \\ Prodi Ilmu Pemerintahan Fakultas Ilmu Sosial dan Ilmu Politik \\ Universitas Riau Kepulauan, Batam Indonesia \\ dendi_sutarto@yahoo.co.id
}

\begin{abstract}
The interconnectivity paradigm, axiologically, wants to offer a new, more open, dialogue and dialogue view of the world of human beings and scientists, able to open dialogue and cooperation, be transparent, accountable to the public and forward-looking. While ontologically, the relationship between the various disciplines of science becomes more open and dialogue of scholarship derived from the texts (Hadlarah al-Nash), and the factualhistorical-empirical scholarly culture, social sciences and the natural sciences (Hadlarah al-Ilm) as well as ethical-philosophical science culture (Hadlarah al-Falsafah). This paper argues that the thought of M. Amin Abdullah contributed greatly to scholarship related to contemporary humanisties approaches, such as hermeneutics, contemporary linguistics, the natural sciences, by revealing the scientific treasures of Bayani, Burhani and Irfani in the Islamic cultural tradition. Both traditions are attempted to compare in matrices and then deliver on a choice of scientific formats that are integrative and interconnective and able to disperse the tensions of religious social conflict in multicultural societies.
\end{abstract}

Keywords: M. Amin Abdullah, integrative-interconetive science, conflict resolution, epistimologi

\begin{abstract}
Abstrak
Paradigma interkoneksitas, secara aksiologi, ingin menawarkan pandangan dunia (word view) manusia beragama dan ilmuan yang baru, yang lebih terbuka, mampu membuka dialog dan kerjasama, transparan, dapat dipertanggungjawabkan secara publik dan berpandangan ke depan. Sedangkan secara ontologis, hubungan antara berbagai disiplin keilmuan menjadi semakin terbuka dan mendialogkan keilmuan bersumber pada teksteks (Hadlarah al-Nash), dan budaya keilmuan faktual-historis-empiris yakni ilmu-ilmu sosial dan ilmu-ilmu kealaman (Hadlarah al-Ilm) serta budaya keilmuan etis-fiosofis (Hadlarah al-Falsafah). Tulisan ini berpendapat bahwa pemikiran M. Amin Abdullah berkontribusi besar bagi keilmuan terkait pendekatan humanisties-kontemporer, seperti hermeneutik, linguistis kontemporer, ilmu-ilmu kealaman, dengan mengungkap kembali kekuatan khazanah keilmuan Bayani, Burhani dan Irfani dalam tradisi budaya Islam. Kedua tradisi tersebut dicoba dibandingkan dalam matrik dan kemudian mengantarkan pada suatu pilihan format keilmuan yang bersifat integratif dan interkonektif dan mampu meredahkan ketegangan konflik sosial keagamaan dalam masyarakat multikulturalisme.
\end{abstract}

Keywords: M. Amin Abdullah, integratif-interkonetif keilmuan, resolusi konflik,epistimologi 


\section{PENDAHULUAN}

Di tengah realitas kehidupan sosial keberagamaan yang kompleks, banyak hal yang menjadi perbincangan baik yang bersifat sosial kemanusiaan, keilmuan, serta wacana kontemporer dan problem keagamaan. Karena berbicara sosial, kemanusiaan, keilmuan dan keagamaan bagaikan matarantai yang salah satunya tidak bisa pisahkan. Terutama khususnya ketika membincangkan persoalan "studi agama dan resolusi konflik". Karena selama ini ada kata-kata yang cukup indah, yaitu Back to al-Qur'an and Hadits, atau meminjam istilah Quraish Sihab "Membumikan Al-Quran", sehingga kemudian banyak asumsi atas dasar keyakinan keagamaan, dengan al-Qur'an semua problematika kehidupan akan mampu untuk dijawab. Namun kemudian muncul pertanyaan bagaimana caranya membumikan al-Qur'an untuk merespon problematika kehidupan yang kompleks?

Belum lagi tradisi pemikiran keislaman yang selama ini masih terkungkung oleh "pemahaman-pemahaman klasik", serta adanya dikotomi yang kuat antara ranah studi keislaman dan ranah keilmuan. Karena dalam studi keislaman al-Qur'an dan Sunnah merupakan hard Core atau objek studi, dimana dimungkinkan munculnya banyak tafsiran dengan berbagai metode dan pendekatan. Karena selama ini ketegangan atau tension masih tampak sangat jelas antara sisi "normativitas" dan "historisitas" keberagamaan khususnya di tanah air. Sehingga untuk mengurangi ketegangan yang seringkali tidak produktif, di sini lah M. Amin Abdullah menawarkan paradigma keilmuan "interkoneksitas" dalam studi Islam kontemporer di Pergurun Tinggi. ${ }^{1}$

Dengan proyek besar reintegrasi epistemologi keilmuan umum dan agama mengandung arti perlunya dialog dan kerjasama antar disiplin ilmu umum dan agama yang lebih erat dimasa yang akan datang. Dengan pendekatan interdisiplinery ${ }^{2}$ dikedepankan, interkoneksitas dan sensitivitas antar berbagai disiplin ilmu-ilmu kealaman dengan disiplin ilmu-ilmu sosial, dan disiplin humanities serta ilmu-ilmu agama perlu di upayakan secara terus menerus, sehingga kedepannya mampu menjawab berbagai tantangan modernisasi, globalisasi dan perkembangan zaman dengan berbagai problematikanya kehidupan yang kompleks.

Di dalam tulisan ini akan membincangkan kembali pemikiran M. Amin Abdullah tentang "Epistemologi Keilmuan Interkonektif-Integratif dalam Ilmu-ilmu Sosial dan

1 M. Amin Abdullah, Islamic Studies di Perguruan Tinggi, Pendekatan Integratif-Interkonektif (Yogyakarta: Pustaka Pelajar, 2006), hlm. vii

${ }^{2}$ M. Amin Abdullah, Islamic Studies di Perguruan Tinggi, Pendekatan Integratif-Interkonektif .... hlm. 399 
Keagamaan". Hal ini tentu sangat penting untuk diperbincangkan terkait berbagai persoalan keagamaan dan kemanusiaan yang masih menyisahkan berbagai problematikanya. Terutama bagaimana relevansi epistimologi Interkonektif-Integratif terhadap penyelesaian berbagai konflik yang terjadi di Indonesia khususnya. Terkaiat dengan tema pembahasan kita, penulis pikir ada dua artikel yang sangat penting menjadi tema pokok yang di tulis oleh M. Amin Abdullah, yaitu; "Etika Tauhidik sebagai Dasar Kesatuan Epistemologi Keilmuan Umum dan Agama: Dari Posistivistik-Sekuleristik ke Teoantroposentristik-Integralistik" dan "Design Pengembangan Akademik IAIN menuju UIN: Dari Pendekatan Dikotomistik-Atomistik ke Integrastif-Interkonektif'.

\section{SEKILAS TENTANG KEHIDUPAN M. AMIN ABDULLAH}

M. Amin Abdullah, lahir di Margomulyo, Tayu, Pati, Jawa Tengah, 28 Juni 1953. pengembaraan intelektualnya di mulai dari studi Kulliyat Al-Mu'allimin Al-Islamiyyah (KMI), Pesantren Gontor Ponorogo pada 1972, dan Program Sarjana Muda (Bakalaureat) pada Institut Pendidikan Darussalam (IPD) pada 1977 di pesantren yang sama. Kemudian hijrah ke Yogyakarta dengan melanjutkan studi di Fakultas Ushuluddin, Jurusan Perbandingan Agama, IAIN Sunan Kalijaga (sekarang UIN Sunan Kalijaga), tahun 1982. Atas sponsor Departemen Agama dan Pemerintah Republik Turki, mulai tahun 1985 M. Amin Abdullah melanjutkan program Ph.D, dalm bidang Filsafat Islam, di Departement of Philosophy, Faculty of Art and Science, Middle East Technical University (METU), Ankara, Turki sampai tahun 1990. Sedangkan Program Post-Doctoral ditempuh di McGill University Kanada. $^{3}$

Sedangkan karya M. Amin Abdullah yang cukup terkenal adalah The Idea of Universality of Ethical Norms in Ghazali and Kant, yang diterbitkan di Turki (Ankara: Turkiye Diyanet Vakfi, 1992). Karya ini merupakan hasil disertasi Ph.D. M. Amin Abdullah di Middle East Technical University (METU), Ankara, Turki. Berbagai karya-karya lainya di antaranya; Falasafah Kalam di Era Postmodernisme (Yogyakarta: Pustaka Pelajar, 1995), Studi Agama: Normativitas atau Historisitas, (Yogyakarta: Pustaka Pelajar, 1996), Dinamika Islam Kultur: Pemetaan atas Wacana Keislaman Kontemporer (Bandung: Mizan, 2000), Pendidikan Agama Era Multikultural Multireligius (Jakarta: PSAP Muhammadiyah, 2005), dan Islamic Studies Di Perguruan Tinggi Pendekatan Integrastif-Interkonektif (Yogyakarta:

${ }^{3}$ M. Amin Abdullah, Islamic Studies di Perguruan Tinggi, Pendekatan Integratif-Interkonektif, hlm. 431. Di akhir buku ini, di tulis lengkap riwayat hidup beliau. 
Pustaka Pelajar, 2006). Serta berbagai karya terjemahan dan berbagai artikel dan makalah seminar Nasional dan Internasional.

Kiprah intelektual M. Amin Abdullah, tidak hanya samapai di situ, namun lebih jauh beliau tetap memberikan kuliah di berbagai perguruan tinggi di Indonesia, khususnya di UIN Suna Kalijaga Yogyakarta. Sedangkan secara struktural-organisatoris, perna terlibat di HMI, PPI Turki, PP Muhammadiyah, Pembantu Rektor I (Bidang Akademik), dan Rektor dari 2002-2005, peridoe ke-2 2005 samapai 2008.

\section{EPISTEMOLOGI KEILMUAN INTERKONEKTIF-INTEGRATIF DALAM ILMU ILMU SOSIAL DAN KEAGAMAAN}

Secara epistemologi, paradigma interkoneksitas merupakan jawaban atau respon terhadap kesulitan-kesulitan yang di rasakan selama ini, yang diwariskan dan diteruskan selama berabad-abad dalam peradaban Islam tentang adanya dikotomi pendidikan umum dan pendidikan agama. Masing-masing berdiri sendiri-sendiri, tanpa merasa perlu saling bertegur sapa. ${ }^{4}$ Kesulitan epistemologi ini rupanya berdampak secara struktural-politis dengan berdirinya Departemen Pendidikan Nasional dan Departemen Agama di awal kemerdekaan Republik Indonesia. Sehingga dalam perkembangannya jurang pemisah atau gap antara keduanya, khususnya dalam wilayah pendidikan semakin tampak.

Paradigma "interkoneksitas" berasumsi bahwa untuk memahami kompleksitas fenomena kehidupan yang dihadapi dan dijalani manusia, setiap bangunan keilmuan apapun, baik keilmuan agama (termasuk agama Islam dan agama-agama yang lain), keilmuan sosial, humaniora, maupun kealaman tidak dapat berdiri sendiri. Begitu ilmu pengetahuan tertentu mengklaim dapat berdiri berdiri sendiri, merasa dapat menyelesaikan persoalan secara sendiri, tidak memerlukan bantuan dan sumbangan dari ilmu yang lain, maka self sufficiency (cukup sendiri) ini cepat atau lambat akan beruba menjadi narrowmindeness (berpandangan sempit) untuk tidak menyebutnya fanatisme partikularitas disiplin keilmuan. Karena dengan adanya kerjasama, saling tegur sapa, saling membutuhkan, saling koreksi dan saling keterhubungan antar disiplin keilmuan akan lebih dapat membantu manusia memahami kompleksitas kehidupan yang di dijalaninya dan sekaligus memecahkan berbagai persoalan yang dihadapinya.

${ }^{4}$ M. Amin Abdullah, Islamic Studies di Perguruan Tinggi, Pendekatan Integratif-Interkonektif..,hlm. 
Paradigma interkoneksitas, secara aksiologi, ${ }^{5}$ ingin menawarkan pandangan dunia (word view) manusia beragama dan ilmuan yang baru, yang lebih terbuka, mampu membuka dialog dan kerjasama, transparan, dapat dipertanggungjawabkan secara publik dan berpandangan ke depan. Sedangkan secara ontologis, hubungan antara berbagai disiplin keilmuan menjadi semakin terbuka dan cair, meskipun blok-blok dan batas-batas wilayah antara budaya pendukung keilmuan agama yang bersumber pada teks-teks (Hadlarah alNash), dan budaya pendukung keilmuan faktual-historis-empiris yakni ilmu-ilmu sosial dan ilmu-ilmu kealaman (Hadlarah al-Ilm) serta budaya pendukung keilmuan etis-fiosofis (Hadlarah al-Falsafah) masih tetap saja ada. ${ }^{6}$ Hanya saja, cara berpikir dan sikap ilmuwan yang membidangi dan menekuni ilmu-ilmu ini yang perlu berubah.

Sehingga di dalam studi agama tidak hanya didekati dan dipahami melalui pendekatan teologis-normatif semata, sesuai dengan konteks yang ada. Maka terjadilah pergeseran paradigma pemahaman terhadap "Agama" (dari “doktrin" ke arah entitas "sosiologis"). Sehingga kemudian banyak ruang untuk melihat dan menginterpretasi "Agama" secara aspektual, dimensional dan bahkan multi-dimensional approaches. Di sini lain "tradisi" agama sulit dipisahakan dari faktor "human construction" yang dipengaruhi oleh perjalanan sejarah sosial, ekonomi-politik, dan kultur. ${ }^{7}$ Lebih lanjut M. Amin Abdullah membedakan antara agama Islam dan pemikiran keislaman seperti (kalam, tasawuf, fiqih dan falsafah), keempat hal tersebut dapat diubah dan diperlukan betuk ijtihad.

Namun meskipun telah mencoba masuk ke tradisi keilmuan baru, seperti filsafat, antopologi, sosiologi, religious studies dan lain-lain. Namun kesinambungan dengan budaya viii

${ }^{5}$ M. Amin Abdullah, Islamic Studies di Perguruan Tinggi, Pendekatan Integratif-Interkonektif... hlm.

6 Istilah tiga hadlarah ini merupakan pinjaman M. Amin Abdullah dari perpaduan buah pikir para pemikir Muslim kontemporer seperti; Mohammed Arkoun, Muhammad Abid al-Jabiry, Nasr Hamid Abu Zaid dalam beberapa bukunya, yang kemudian M. Amin Abdullah olah dengan ilustrasi yang saling melengkapi.

7 Amin Abdullah, Studi Agama Normativitas atau Historisitas? (Yogyakarta: Pustaka Pelajar.2004), hlm. 13. Lihat juga hasil wawancara Ulil Abshar-Abdalla dari (JIL) dengan Prof. Dr. M. Amin Abdullah, Rektor UIN Yogyakarta, dalam rangka mengapresiasi kedatangan Prof. Dr. Nasr Hamid Abu Zayd, di Indonesia, yang berlangsung Kamis (26/08/2004). http://islamlib.com/id/artikel/bedakan-antara-agama-dan-pemikirankeagamaan/ 06 Juni 09. Dari hasil wawancara dengan tema "Bedakan antara Agama dan Pemikiran Keagamaan" kemudian M. Amin Abdullah menjelaskan yang dimaksud dengan historisitas adalah adanya dimensi perubahan (sosial-politik-ekonomi-budaya) dalam sebuah masyarakat. Kalau kita menggunakan paradigma Alfin Tofler, mirip seperti pergantian era dari agraris, industri, dan informasi. Dalam peralihanperalihan itu terjadi proses change atau perubahan. Aspek-aspek perubahan itu turut diperhatikan dalam penelaahan terhadap kitab suci. Nah, al-qirâ'ah al-muntijah adalah membaca dengan mempertimbangkan pemehaman seseorang atau kelompok terhadap perubahan-perubahan sejarah itu. Yang dimaksud sebetulnya adalah sesederhana itu. Intinya, pembacaan yang produktif akan selalu mempertimbangkan aspek historisitas (târikhîyyah), baik dari sisi sosial, budaya, ekonomi, maupun politik. 
nash atau teks-teks keagamaan sebelumnya tetap dipelihara. Sehingga hubungan ini bisa dalam bentuk melanjutkan, memperdalam, mengkritik, mengoreksi, memperluas, memformulasi ulang rumusan keilmuan terdahulu dan begitu seterusnya. Sehingga dalam upaya mendorong kerjasama dan tegur sapa antara penganut tradisi tekstual-filologi dan kontekstual-sosiologis ditambah perlunya transendensi-filosofi untuk dapat keluar dari belenggu dan jebakan-jebakan kultur-sosiologis, lebih-lebih politis yang tidak dapat dihindari.

Terkait ketiga hal tersebut di atas, kemudian M. Amin Abdullah memasukkan pendekatan humanisties-kontemporer, seperti hermeneutik, linguistis kontemporer, ilmu-ilmu kealaman, berbarengan dengan mengungkap kembali kekuatan khazanah keilmuan Bayani, Burhani dan Irfani dalam tradisi budaya Islam. Kedua tradisi tersebut dicoba dibandingkan dalam matrik dan kemudian mengantarkan pada suatu pilihan format bangunan keislaman di Perguruan Tinggi yang lebih bersifat integratif dan interkonektif. ${ }^{8}$

\section{DARI PARADIGMA POSITIVISTIK-SEKULERISTIK KE ARAH TEOANTROPOSENTRIK-INTEGRALISTIK}

Samapi saat ini, masih kuatnya anggapan dalam masyarakat luas yang mengatakan bahwa "agama" dan "ilmu" adalah dua entitas yang tidak bisa dipertemukan. Keduanya mempunyai wilayah sendiri-sendiri, yang terpisah satu dengan yang lainnya, baik dari segi objek formal-material, metode penelitian, kriteria kebenaran, peran yang dimainkan oleh ilmuwan maupun status teori masing-masing dan bahkan sampai pada institusi penyelenggara. Dengan kata lain, ilmu tidak mempedulikan agama dan agama tidak mempedulikan ilmu. Sehingga batas dikotomik antara pengetahuan umum dan pengetahuan agama harus diubah menjadi bangunan keilmuan baru yang lebih holistik-integralistik atau paling tidak bersifat komplementer. ${ }^{9}$

Karena tantangan di era globalisasi menuntut respon tepat dan cepat dari sistem pendidikan Islam secara keseluruhan. Jika kaum Muslimin tidak hanya ingin sekedar survive di tengah persaingan global yang semakin tajam dan ketat, tetapi juga berharap mampu tampil di depan, maka reorientasi pemikiran pendidikan Islam dan rekonstruksi sistem dan kelembagaan merupakan keniscayaan. Karena globalisasi berdampak pada hampir seluruh

$\mathrm{xi}$

${ }^{8}$ M. Amin Abdullah, Islamic Studies di Perguruan Tinggi, Pendekatan Integratif-Interkonektif... hlm.

${ }^{9}$ M. Amin Abdullah, Menyatukan Kembali Ilmu-ilmu Agama dan Umum: Upaya mempertemukan Epistemologi Islam dan Umum (Yogyakarta: SUKA Press, 2003), hlm.7 
aspek kehidupan, baik fisik, sosial, kejiwaan ataupun agama, sehingga globalisasi ilmu dan budaya tidak menutup kemungkinan akan melahirkan "culture shock" bagi yang belum siap.

Sehingga dengan pemikiran inilah mendorong adanya pengembangan proyek keilmuan dengan kerangka epitemologi keilmuan dan etika moral keagamaan yang integralistik. Serta dimensi "pemikiran" (thought, al-fikr) dan dimensi "sejarah" (histori, altarikh) membentuk hubungan circular (al-dairy), yakni hubungan yang melingkar yang tidak ada putus-putusnya. Hubungan tersebut bukan hubungan "atomistik" (terpotong-potong tidak berkesimanbungan). ${ }^{10}$ Menurut telaah filsafat ilmu, hampir semua jenis kegiatan ilmu pengetahuan, baik natural science maupun social science, bahkan religious science, selalu mengalami apa yang disebut dengan shifting paradigm (pergeseran gugus keilmuan). Karena ilmu pengetahuan selama ini bersifat historis, karena di bangun oleh akal budi manusia secara historis. ${ }^{11}$

Agama dalam arti luas merupakan wahyu Tuhan, yang mengatur hubungan manusia dengan Tuhan, diri-sendiri, dan lingkungan hidup baik fisik, sosial maupun budaya secara global., atau seperangkat aturan-aturan, nilai-nilai umum dan prinsip dasar inilah yang disebut "Syariat". Kitab suci Al-Quran merupakan petunjuk, etika, moral, akhlak, kebijaksanaan dan dapat menjadi teologi ilmu serta grand theory ilmu. Wahyu tidak perna mengklaim sebagai ilmu untuk ilmu seperti diklaim ilmu-ilmu sekuler. ${ }^{12}$ Agama memang mengklaim sebagai sumber kebenaran, etika, hukum, dan pengetahuan. Agama tidak perna menjadikan wahyu Tuhan sebagai satu-satunya sumber pengetahuan. Menurut pandangan ini, sumber pengetahuan ada dua macam, yaitu pengetahuan yang berasal dari Tuhan, dan pengetahuan yang berasal dari manusia. Perpaduan antara keduanya inilah disebut sebagai teoantroposentris. $^{13}$

Walaupun banyak cerdik pandai telah tertipu. Ilmu-ilmu sekuler yang mengklaim sebagai value free (bebas nilai dan kepentingan) ternyata penuh dengan kepentingan. Kepentingan itu di antaranya dominasi ekonomi, militer, kebudayaan Barat (Orientalisme). Diharapkan ilmu yang lahir bersama etika agama tidak boleh memihak atau partisan. Produk ilmu harus bermanfaat untuk seluruh umat manusia tanpa memandang corak agama, bangsa,

\footnotetext{
10 M. Amin Abdullah, Falsafah Kalam Di Era Postmodrnisme (Yogyakarta: Pustaka Pelajar, 1997), hlm. 66

11 M. Amin Abdullah, dkk, Re-strukturisasi Metodologi Islamic Studies Mazhab Yogyakarta (Yogyakarta: SUKA Press, 2007), hlm. 4

12 M. Amin Abdullah, dkk, Menyatukan Kembali Ilmu-ilmu Agama dan Umum: Upaya mempertemukan Epistemologi Islam dan Umum...hlm. 9

13 M. Amin Abdullah, Menyatukan Kembali Ilmu-ilmu Agama dan Umum: Upaya mempertemukan Epistemologi Islam dan Umum...hlm. 10. Lihat juga M. Amin Abdullah, Islamic Studies di Perguruan Tinggi, Pendekatan Integratif-Interkonektif...hlm.102
} 
kulit maupun etnis (rahmatan lil'alamin). Paradigma keilmuan baru yang menyatukan, bukan sekedar menggabungkan wahyu Tuhan dan temuan pikiran manusia (ilmu-ilmu holistikintegralistik), itu tidak mengecilkan peran Tuhan (sekulerisme) atau mengecilkan manusia dari dirinya sendiri, dari masyarakat sekitarnya, dan lingkungan.

Dari diskusi keagamaan kontemporer jelas bahwa "agama" ternyata mempunyai wajah (multifaces) dan bukan lagi seperti orang dahulu memahaminya, yakni hanya sematamata terkait dengan persoalan ketuhanan, kepercayaan, keimanan, pedoman hidup dan seterusnya. Dari studi historis-empiris terhadap fenomena keagamaan diperoleh masukan bahwa agama sesungguhnya juga sarat oleh berbagai "kepentingan". Sehingga sangat sulit menjumpai agama tanpa "interest", betapa tingginya nilai transendental dan sosial yang dikandung oleh kepentingan. ${ }^{14}$

Kedepannya diharapkan konsep integralisme dan reintegrasi epistemologi keilmuan sekaligus akan dapat menyelesaikan konflik antar sekulerisme ekstrem dan fundamentalisme negatif agama-agama yang rigid dan radikal dalam banyak hal. ${ }^{15}$ Karena agama menjadi objektivikasi ilmu dalam arti bahwa ilmu dari orang beriman untuk seluruh manusia, tidak hanya untuk yang beriman saja. Sehingga diharapkan pola kerja keilmuan yang integraslistik dengan basis moralitas keagamaan yang humanis, yang dituntut memasuki wilayah yang lebih luas seperti psikologi, sosiologi, antropologi, kesehatan, teknologi, ekonomi, politik, hubungan internasional dan seterusnya.

Dari gambar di bawah ini mengilustrasikan hubungan jaring laba-laba yang bercorak teoantroposentris-integralistik. Tergambar dari horizon keilmuan integraslistik begitu luas. Sekaligus terampil dalam kehidupan sektor tradisional maupun modern karena dikuasainya salah ilmu dasar dan keterampilan dalam menghadap era informasi. Di samping itu juga tergambar sosok manusia beragama (Islam) yang terampil dalam menganalisis isu-isu yang menyentuh problem kemanusiaan dan keagamaan di era modern, dengan dikuasainya pendekatan baru yang diberikan oleh ilmu-ilmu natural science, social science dan humanities.

\section{Horizon Keilmuan \\ Jaring Laba-laba Keilmuan Teoantoposentrik-Integralistik}

\footnotetext{
14 M. Amin Abdullah, Pengantar, dalam Mircea Aliade, dkk, terj, Ahmad Norman Permata, Metodologi Studi Agama (Yogyakarta: Pustaka Pelajar, 2000), hlm. 1

${ }_{15}$ M. Amin Abdullah, Menyatukan Kembali Ilmu-ilmu Agama dan Umum: Upaya mempertemukan Epistemologi Islam dan Umum...hlm. 11
} 


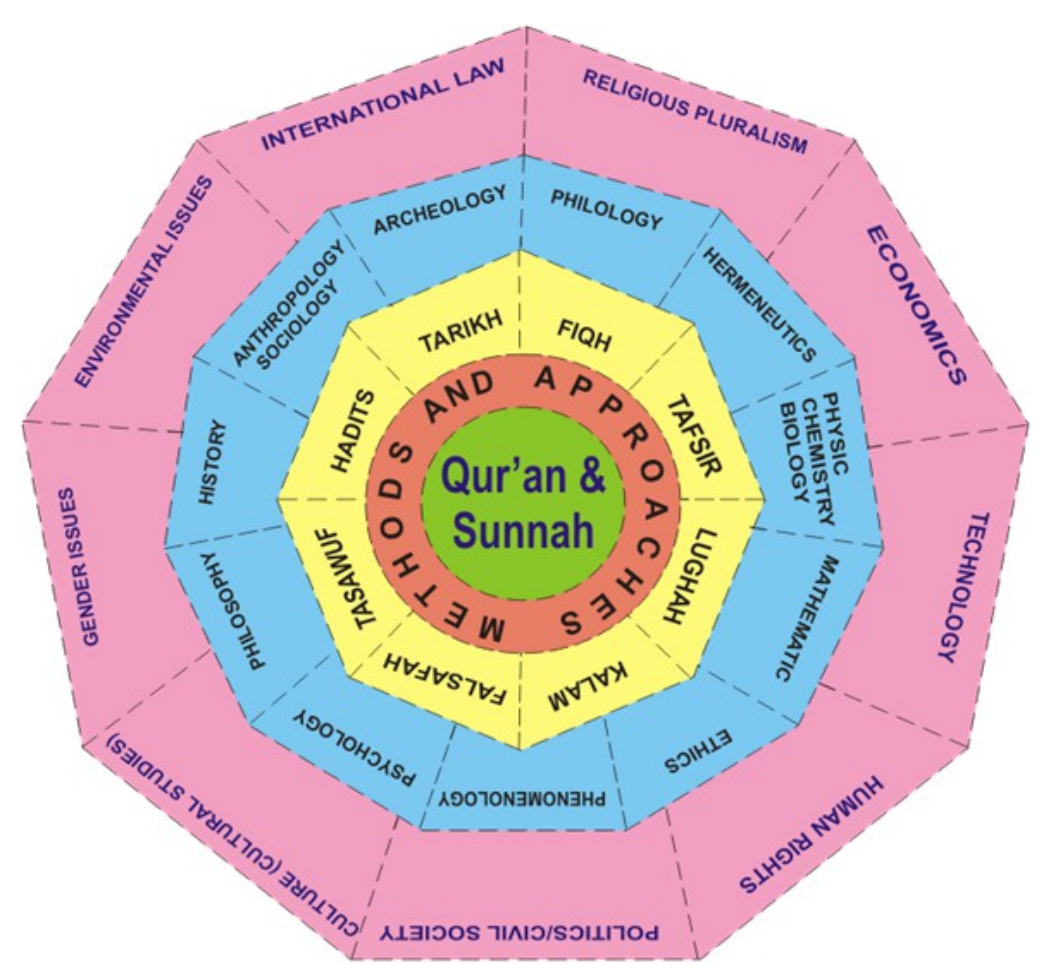

Kondisi yang ada sekarang ini menunjukkan bahwa radius daya jangkau aktivitas keilmuan dan lebi-lebi pendidikan agama di Perguruan Tinggi Agama, misalnya IAIN dan STAIN di seluruh tanah air, hanya terfokus pada lingkaran 1 dan jalur lingkar lapis 2 (Kalam, Falsafah, Tasawuf, Hadis, Tarikh, Fiqih, Lughah). Itu pun boleh dibilang hanya terbatas pada ruang gerak pendekatan keilmuan humaniora klasik. Sedangkan IAIN pada umumnya sekarang ini belum mampu memasuki diskusi ilmu-ilmu sosial dan humanities kontemporer seperti yang tergambar pada jalur lingkaran 2 (Antropologi, Sosiologi, Filsafat, dan berbagai teori dan pendekatan yang ditawarkannya). Akibatnya terjadi jurang wawasan keislaman yang tidak terjembatani antara ilmu-ilmu keislman klasik dan ilmu-ilmu keislaman baru yang telah memanfaatkan analisis ilmu-ilmu sosial dan humaniora kontemporer, bahkan juga ilmuilmu alam. ${ }^{16}$

Sedangkan isu-isu sosial, politik, ekonomi, keagamaan, militer, gender, lingkungan, ilmu-ilmu sosial dan humanities kontemporer pasca modern, seperti yang tergambar pada jalur lingkar lapis 3 hampir-hampir tidak tersentuh oleh ilmu-ilmu sosial dan kajian keislaman di tanah air, khususnya di STAIN dan IAIN. Sehingga ungkapan seperti "to be religious today is to be interreligious" terasa masih sangat absurd (mustahil) dan unthinkable

16 M. Amin Abdullah, Menyatukan Kembali Ilmu-ilmu Agama dan Umum: Upaya mempertemukan Epistemologi Islam dan Umum...hlm. 13-14. Lihat juga M. Amin Abdullah, Islamic Studies di Perguruan Tinggi, Pendekatan Integratif-Interkonektif...hlm.107-108 
(tidak dapat dipertimbangkan alias tidak mungkin) untuk dipikirkan bagi tradisi keilmuan lingkar lapis 2, meskipun era globalisasi-informasi memaksa manusia beragama di era sekarang untuk berpikir demikian. ${ }^{17}$

Karena ketika ilmu-ilmu Kauniyyah (Iptek, atau science and technology) ini terpisah jauh dari inti ilmu-ilmu Qauliyyah (Teks-naskah), dan kemudian masing-masing berdiri sendiri-sendiri, tanpa kontak atau tegur sapa. Bahkan nyaris seringkali terjadi bahwa ilmuilmu keagamaan Islam sering ditampilkan tidak dapat membekali perangkat lunak untuk menjaga, memelihara, mengawasi, dan mengontrol dengan mengkritik moralitas dan kesalehan publik.

\section{RELEVANSI EPISTEMOLOGI KEILMUAN INTEGRATIF-INTERKONEKTIF DALAM ILMU-ILMU SOSIAL DAN KEAGAMAAN TERHADAP RESOLUSI KONFLIK.}

Dari uraian tentang epistemologi keilmuan Integratif-Interkonektif M. Amin Abdullah di atas, penulis pikir secara tidak langsung telah menghantarkan kita pada sebuah proses pemaknaan ulang (reinterpretasi atau bahkan rekonstruksi) atas kehidupan keberagamaan dan respon terhadap terhadap berbagai problematika kemanusiaan. Sehingga secara sederhana melalui pendekatan interdisiplinery studies, mencoba melihat berbagai problematika kemanusian dan berbagai wacana kontemporer seperti (gender, HAM, kemiskinan, globalisasi, pluralitas, lingkungan, multikultural dan keagamaan), dengan mempertimbangan berbagai pendekatan keilmuan yang beragam dan relevan.

Pada pendekatan Dikotomistik-Atomistik (yang lebih tetutup, atau hanya berjalan masing-masing tanpa mempertimbangakan keilmuan atau aspek lain) dapat di geser ke arah pendekatan Integrastif-Interkonektif, yang lebih terbuka. Seperti asumsi dasar pendekatan interkonektif, bahwa untuk memahami kompleksitas fenomena kehidupan yang dihadapi dan dijalani manusia, setiap bangunan keilmuan apapun, baik keilmuan agama (termasuk agama Islam dan agama-agama yang lain), keilmuan sosial, humaniora, maupun kealaman tidak dapat berdiri sendiri. Sekaligus mempunyai etika atau nilai moralitas pengetahuan yang berasal dari Tuhan, dan pengetahuan yang berasal dari manusia. Sehingga perpaduan antara keduanya inilah disebut sebagai teoantroposentris.

Kalau kita cermati samapai saat ini masih banyak menyisahkan berbagai konflik, violence, atau bahkan perang yag mengatasnamakan agama. Karena selama ini seringkali hlm.109

\footnotetext{
${ }^{17}$ M. Amin Abdullah, Islamic Studies di Perguruan Tinggi, Pendekatan Integratif-Interkonektif...
} 
agama dipandang sebagai non-falsifiable postulated ${ }^{18}$ (banyak penganut agama menyakini pemahaman agama tidak bisa di kritik atau agama sudah selesai). Padahal proses beragama yang telah membentuk institusionalisasi agama dalam kehidupan sosilogis telah mengalami diferensiasi yang tajam sebagai konsekuensi keberagamaan manusia, karena di sisi lain kenyataan tradisi telah membentuk pola pemikiran menjadi sebuah bentuk social constructed. ${ }^{19}$ Sulit untuk dihindari perbedaan yang tajam ditengah pluralitas yang kompleks, apalagi menyangkut agama sebagai keyakinan dan sekaligus institusi sosial dimana agama telah menjadi bagian kehidupan yang tidak bisa dipisahkan dengan berbagai aspek, seperti politik, ekonomi, budaya, dan aktifitas sosial lainnya.

Karena seluruh agama-agama justru memuat pesan suci (Sacred), peace (damai), equilibrium (keharmonisan). Namun di sisi agama tidak selamanya dianggap "suci” karena "teologi" bukanlah Tuhan itu sendiri, bahkan menurut W.C. Smith "theology is part of the tradition, is part of this word". Karena teologi adalah bagian tradisi yang tidak bisa lepas dari interpensi manusia. Sehingga selama tidak ada keterbukaan dalam kehidupan beragama, maka selama itu pula agama selalu dihadirkan dalam wajah yang tidak humanis, yang tidak bisa lepas dari konflik laten. Karena selalu diwarnai oleh diskriminasi, ketidakadilan, unfairness, violence, karena masing-masing menyakini bahwa cara berpikir, pemahaman mereka yang paling benar, padahal kadang tidak sadar itu semu penuh dengen kepentingan.

\section{KESIMPULAN}

Pemikiran filsafat M. Amin Abdullah tentang "Epistemologi Keilmuan InterkonektifIntegratif dalam Ilmu-ilmu Sosial dan Keagamaan". Hal ini tentu sangat penting untuk diperbincangkan terkait berbagai persoalan keagamaan dan kemanusiaan yang masih menyisahkan berbagai problematikanya, dan tentu relevansi epistimologi InterkonektifIntegratif terhadap penyelesaian berbagai konflik yang terjadi di Indonesia khususnya sangat diperlukan sebagai kerangka pemiiran yang lebih eksklusif dan multi interdisiplinery studies.

18 Kuliah "Filsafat Agama dan Resolusi Konflik" bersama M. Amin Abdullah, pada 05 November 2008. Dari hasil kuliah tetang "Agama dan Legitimasi Konflik", dapat disimpulkan bahwa konstruksi pemahaman kita tentang agama kitalah yang paling benar, sehingga kecurigaan, ketakutan, yang melahirkan resistensi terhadap aliran yang berbeda, agama lain atau bahkan modernisasi. Sehingga di sini sangat dibutuhkan nalar kristis beragama, teutama dalam melihat persoalan (Dogma (belief), Ritual agama, Text, Pemimpin agama, Historisitas agama, dan Legitimated morality).

${ }^{19}$ Peter L. Berger dan Thomas Luckman, The Social Contruction of Reality, (terj), Hasan Basri, Tafsir Sosial Atas kenyataan (Jakarta: LP3ES, 1990). Lihat Peter L. Berger, The Sacred Canopy, (terj), Hartono, Langit Suci Agama Sebagai Realitas Sosial (Jakarta: LP3ES, 1991) 
Secara epistemologi, paradigma interkoneksitas merupakan jawaban atau respon terhadap kesulitan-kesulitan yang di rasakan selama ini, yang diwariskan dan diteruskan selama berabad-abad dalam peradaban Islam tentang adanya dikotomi pendidikan umum dan pendidikan agama. Masing-masing berdiri sendiri-sendiri, tanpa merasa perlu saling bertegur sapa. Kesulitan epistemologi ini rupanya berdampak secara struktural-politis dengan berdirinya Departemen Pendidikan Nasional dan Departemen Agama di awal kemerdekaan Republik Indonesia. Sehingga dalam perkembangannya jurang pemisah atau gap antara keduanya, khususnya dalam wilayah pendidikan semakin tampak.

Paradigma "interkoneksitas" berasumsi bahwa untuk memahami kompleksitas fenomena kehidupan yang dihadapi dan dijalani manusia, setiap bangunan keilmuan apapun, baik keilmuan agama (termasuk agama Islam dan agama-agama yang lain), keilmuan sosial, humaniora, maupun kealaman tidak dapat berdiri sendiri. Begitu ilmu pengetahuan tertentu mengklaim dapat berdiri berdiri sendiri, merasa dapat menyelesaikan persoalan secara sendiri, tidak memerlukan bantuan dan sumbangan dari ilmu yang lain, maka self sufficiency (cukup sendiri) ini cepat atau lambat akan beruba menjadi narrowmindeness (berpandangan sempit) untuk tidak menyebutnya fanatisme partikularitas disiplin keilmuan. Karena dengan adanya kerjasama, saling tegur sapa, saling membutuhkan, saling koreksi dan saling keterhubungan antar disiplin keilmuan akan lebih dapat membantu manusia memahami kompleksitas kehidupan yang di dijalaninya dan sekaligus memecahkan berbagai persoalan yang dihadapinya.

Paradigma interkoneksitas, secara aksiologi, ingin menawarkan pandangan dunia (word view) manusia beragama dan ilmuan yang baru, yang lebih terbuka, mampu membuka dialog dan kerjasama, transparan, dapat dipertanggungjawabkan secara publik dan berpandangan ke depan. Sedangkan secara ontologis, hubungan antara berbagai disiplin keilmuan menjadi semakin terbuka dan cair, meskipun blok-blok dan batas-batas wilayah antara budaya pendukung keilmuan agama yang bersumber pada teks-teks (Hadlarah alNash), dan budaya pendukung keilmuan faktual-historis-empiris yakni ilmu-ilmu sosial dan ilmu-ilmu kealaman (Hadlarah al-Ilm) serta budaya pendukung keilmuan etis-fiosofis (Hadlarah al-Falsafah) masih tetap saja ada. Hanya saja, cara berpikir dan sikap ilmuwan yang membidangi dan menekuni ilmu-ilmu ini yang perlu berubah.

Sehingga di dalam studi agama tidak hanya didekati dan dipahami melalui pendekatan teologis-normatif semata, sesuai dengan konteks yang ada. Maka terjadilah pergeseran paradigma pemahaman terhadap "Agama" (dari “doktrin” ke arah entitas "sosiologis"). 
Sehingga kemudian banyak ruang untuk melihat dan menginterpretasi "Agama" secara aspektual, dimensional dan bahkan multi-dimensional approaches. Di sini lain "tradisi" agama sulit dipisahakan dari faktor "human construction" yang dipengaruhi oleh perjalanan sejarah sosial, ekonomi-politik, dan kultur. Lebih lanjut M. Amin Abdullah membedakan antara agama Islam dan pemikiran keislaman seperti (kalam, tasawuf, fiqih dan falsafah), keempat hal tersebut dapat diubah dan diperlukan betuk ijtihad

\section{DAFTAR PUTAKA}

Abdullah, M. Amin, Falsafah Kalam Di Era Postmodrnisme, Yogyakarta: Pustaka Pelajar, 1997

Pengantar, dalam Mircea Aliade, dkk, terj, Ahmad Norman Permata, Metodologi Studi Agama (Yogyakarta: Pustaka Pelajar, 2000

, Menyatukan Kembali Ilmu-ilmu Agama dan Umum: Upaya mempertemukan Epistemologi Islam dan Umum, Yogyakarta: SUKA Press, 2003

Pelajar.2004

Studi Agama Normativitas atau Historisitas? Yogyakarta: Pustaka

Islamic Studies di Perguruan Tinggi, Pendekatan IntegratifInterkonektif, Yogyakarta: Pustaka Pelajar, 2006

, dkk, Re-strukturisasi Metodologi Islamic Studies Mazhab Yogyakarta, Yogyakarta: SUKA Press, 2007

"Filsafat Agama dan Resolusi Konflik" Kuliah langsung dengan M. Amin Abdullah, pada 05 November 2008.

Berger, Peter L. dan Thomas Luckman, The Social Contruction of Reality, (terj), Hasan Basri, Tafsir Sosial Atas kenyataan, Jakarta: LP3ES, 1990

Berger, Peter L, The Sacred Canopy, (terj), Hartono, Langit Suci Agama Sebagai Realitas Sosial, Jakarta: LP3ES, 1991

Carter, Judy and Gordon S. Smith, Religious Peacebuilding: From Potential to Action, within Harold Coward and Gordon S. Smith (Eds), Religion and Peace Building, Albany: State University on New York Press, 2004 
Forward, Martin, Inter-religious Dialoque, A Short IntroductionI, Oxford: Oneword, 2001

Goddard, Hugh, Cristians and Muslim; From Daouble Sstandars to Mutual Understanding, Surry: Curzon Press, 1995 